\title{
Molecular and morphological validation of the species of the genus Actinia (Actiniaria: Actiniidae) along the Atlantic Iberian Peninsula
}

\author{
Ana M. Pereira ${ }^{\mathrm{a}, *}$, Emília Cadeireiro ${ }^{\mathrm{a}}$, Oscar Ocaña ${ }^{\mathrm{b}}$, Jasna Vukićc ${ }^{c}$, Radek Šanda ${ }^{\mathrm{d}}$, \\ Luca Mirimin $^{\mathrm{e}}$, Joana I. Robalo ${ }^{\mathrm{a}}$ \\ ${ }^{a}$ MARE - Marine and Environmental Sciences Centre, ISPA - Instituto Universitário, Rua Jardim do Tabaco 34, 1149-041 Lisboa, Portugal \\ ${ }^{\mathrm{b}}$ Fundación Museo del Mar de Ceuta, Muelle España s/n, 51001 Ceuta, North Africa, Spain \\ ${ }^{\mathrm{c}}$ Department of Ecology, Faculty of Science, Charles University in Prague, Viničná 7, 12844 Prague, Czech Republic \\ ${ }^{\mathrm{d}}$ National Museum, Department of Zoology, Václavské nám. 68, 11579 Prague, Czech Republic \\ e Marine and Freshwater Research Centre, Department of Natural Sciences, School of Science and Computing, Galway-Mayo Institute of \\ Technology, Dublin Road, H91 T8NW, Galway, Ireland
}

\section{A R T I C L E I N F O}

\section{Article history:}

Received 14 April 2020

Received in revised form 28 January 2021

Accepted 28 January 2021

Available online 30 January 2021

\section{Keywords:}

Actinia equina

Actinia fragacea

Actinia schmidti

Cnidaria

Cnidom structures

DNA

\begin{abstract}
A B S T R A C T
The discrimination between the several species of the genus Actinia occurring in the Northeastern Atlantic and Mediterranean has been made analyzing morphological characters, with emphasis on external coloration patterns and morphology of cnidom structures. In Iberia, the occurrence of more than two species of Actinia has been suggested, but its validity is yet to be confirmed. In this paper, the identity of the species of the genus Actinia occurring along the Atlantic Iberian coast is investigated, analyzing morphological and molecular procedures. For this purpose, genetic data was collected from 140 individuals and two genetic markers were amplified and sequenced (the nuclear 28S and the mitochondrial 165 ribosomal genes). The genetic identification was corroborated by morphological analysis of individuals representing each of the genetic groups found. This procedure led to the identification of three species occurring in the studied area - Actinia equina (L.), A. fragacea Tugwell and A. schmidti Monteiro, Sole-Cava \& Thorpe.
\end{abstract}

(c) 2021 Published by Elsevier B.V.

\section{Introduction}

The genus Actinia L. is one of the most diversified and widespread of the Anthozoa (Fautin, 2016). It comprises 62 extant species, according to WORMS (Daly and Fautin, 2020). One of its most ubiquitous species, the beadlet sea anemone Actinia equina (L.), is considered to live in rocky intertidal and subtidal areas, down to depths of $20 \mathrm{~m}$. It is characterized by highly variable coloration patterns, with tentacles being plain and the column plain or mottled, ranging from red, brown and orange to green colors. Historically, this species was known to occur from North Russia and the Baltic Sea to tropical West African waters, including also the archipelagos of Madeira, Azores and Canaries, South Africa, the Mediterranean and Black Sea, the Red Sea and the Far East (Stephenson, 1935; Manuel, 1981; Cha et al., 2004). In the last decades, several morphotypes or populations of $A$. equina have acquired distinct taxonomic statuses - e.g. A. fragacea Tugwell corresponding to a red or dark-red morphotype with a spotted column (Carter and Thorpe, 1981); A. prasina Gosse in the Isle of Man, a local green morphotype (Solé-Cava and

\footnotetext{
* Corresponding author.

E-mail address: ana_pereira@ispa.pt (A.M. Pereira).
}

Thorpe, 1987); A. schmidti Monteiro, Sole-Cava \& Thorpe, in the Mediterranean; and A. ebhayiensis Schama et al., 2012 in South Africa. In Macaronesia, three other species were described: Actinia sali Monteiro, Sole-Cava \& Thorpe in Cape Verde, A. nigropuctata den Hartog \& Ocaña in Madeira and Canary Islands and A. virgata Johnson, from Madeira. Species identification is relatively easy in live individuals with non-plain coloration patterns in the body column. However, for species displaying monochromatic patterns (red, orange, green or brown), species identification has been carried out using morphological analysis of specific characters (namely means and ranges of length and width of different types of nematocysts within different body regions) or genetic data (allozimes) (e.g. Monteiro et al., 1997; Ocaña et al., 2005; Schama et al., 2012). The recent identification of so many species within this genus and the existence of a diffuse literature on this field resulted in some uncertainties on the distribution limits for each species (including $A$. equina), and on the diversity within this genus in several geographic areas.

A previous study on the genetic analyses of the genus Actinia from the Portuguese mainland coast (using a fragment of the $28 \mathrm{~S}$ gene) revealed the existence of two distinct genetic groups, one very common and the other rarer (Pereira et al., 2014). Almost all morphotypes were present in both groups, which were separated 


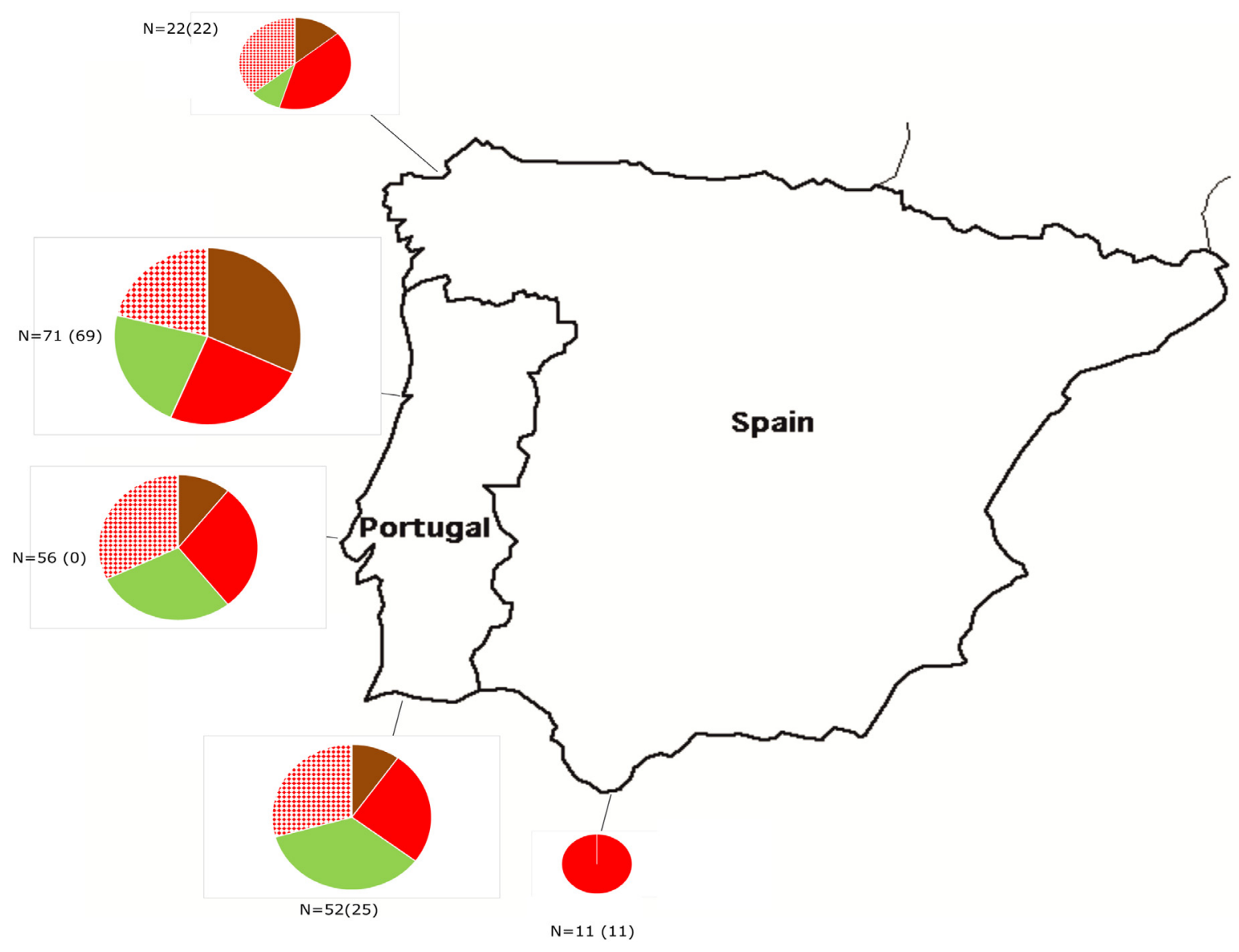

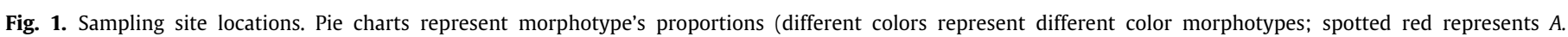

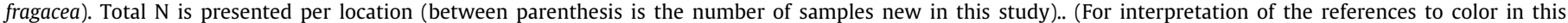
figure legend, the reader is referred to the web version of this article.)

by 24 mutations in a parsimony network, with the same magnitude of the distance found between different species. The same study suggested that the two species, A. equina and A. fragacea, were not valid species, at least along the Portuguese coast, and that some level of cryptic speciation was present in this area, as the distance between the two genetic groups was compatible with distinct species (average uncorrected p distance between the two genetic groups was $1.5 \%$ ). Other genetic studies of this genus are still lacking. In fact, there are no sequences available from the $28 \mathrm{~S}$ gene of any species apart from the ones studied in Pereira et al. (2014), which is one of the molecular markers widely used in the phylogenetic studies in this taxonomic groups (Daly et al., 2010).

The present study aims to clarify the number of taxonomic entities of the genus Actinia occurring along the Iberian Peninsula, increasing the number of individuals analyzed and expanding the sampling area. Here, genetic analyses of fragments of the nuclear $28 \mathrm{~S}$ and the mitochondrial $16 \mathrm{~S}$ ribosomal genes are complemented by morphological analysis of cnidom structures from representative individuals from each of the genetic groups found, allowing for a combined morphological and genetic identification of the species.

\section{Materials and methods}

Tissue samples were collected from 140 individuals, from 11 locations, which were originally identified by inspection of external morphology and coloration (as defined by Schmidt, 1972; Ocaña et al., 2005) (Fig. 1). These included 103 Actinia spp. (plain external color) and 37 A. fragacea (body column red with yellow spots) (Table 1). A small clip was taken from the pedal disk of the anemones that easily cicatrize and regenerate the extirpated tissue, hence minimizing harmful consequences for the animals. Samples were preserved in $96 \%$ ethanol and tissue vouchers were deposited in the collections of MARE-ISPA. Total genomic DNA was extracted with the REDExtract-N-Amp kit (R4775, SigmaAldrich) following the manufacturer's instructions. A total of 1012 bp of the nuclear DNA fragment coding for the ribosomal $28 \mathrm{~S}$ subunit was amplified using the primers LSU D1D2 FW1 (5'-AGC GGA GGA AAA GAA ACT A-3') and LSU D1D2 Rev1 (5'-TAC TAG AAG GTT CGA TTA GTC-3') (Sonnenberg et al., 2007) and the following thermal cycling protocol: $94{ }^{\circ} \mathrm{C}$ for $2 \mathrm{~min}, 45$ cycles of $\left[94{ }^{\circ} \mathrm{C} 20 \mathrm{~s}, 52.5{ }^{\circ} \mathrm{C} 20 \mathrm{~s}, 72{ }^{\circ} \mathrm{C} 90 \mathrm{~s}\right.$ ], $72{ }^{\circ} \mathrm{C}$ for $8 \mathrm{~min}$. For the amplification of a fragment of the $16 \mathrm{~S}$ mtDNA gene $(434 \mathrm{pb})$, the primers ANEM 16A (5'- CAC TGA CCG TGA TAA TGT AGC GT-3') and ANEM 16B (5'-CCC CAT GGT AGC TTT TAT TCG-3') (Geller and Walton, 2001) and the following thermal cycling protocol was used: $94{ }^{\circ} \mathrm{C}$ for $2 \mathrm{~min}, 35$ cycles of $\left[94{ }^{\circ} \mathrm{C} 30 \mathrm{~s}, 46{ }^{\circ} \mathrm{C} 45 \mathrm{~s}, 72{ }^{\circ} \mathrm{C}\right.$ 1 minute], $72{ }^{\circ} \mathrm{C} 10 \mathrm{~min}$. The nuclear $28 \mathrm{~S}$ gene (both directions) and the mitochondrial $16 \mathrm{~S}$ gene (reverse only) fragments were sequenced in a $3700 \mathrm{ABI}$ DNA sequencer using the Big Dye terminator DNA sequencing kit (Applied Biosystems). Chromatograms were visually checked for quality and detection of anomalies and sequences were posteriorly edited using CodonCode Aligner v5.0.1 (CodonCode Corporation, USA). Clustal X (Thompson et al., 1997) was used for sequence alignment, including all previously published sequences from the same locations (Genbank Accession Nos. KP065497-KP065560, KP065565-KP065587 and KP090856KP090932; Pereira et al., 2014; Table 1). Sequences of individuals 
Table 1

Number of samples per sampling site location and species for the $28 \mathrm{~S}$ gene analysis.

\begin{tabular}{|c|c|c|c|c|c|c|c|c|c|}
\hline Species & Region & Sampling site & Coordinates & $28 \mathrm{~S}$ gene & & & 16S gene & & \\
\hline & & & & $\begin{array}{l}\text { This study ( } \mathrm{N} \text { and } \\
\text { GenBank accession } \\
\text { numbers) }\end{array}$ & $\begin{array}{l}\text { Published } \\
\text { sequences } \\
\text { ( } \mathrm{N} \text { and GenBank } \\
\text { accession numbers) }\end{array}$ & $\begin{array}{l}\mathrm{N} \text { (pooled } \\
\text { data) }\end{array}$ & $\begin{array}{l}\text { This study ( } \mathrm{N} \text { and } \\
\text { GenBank accession } \\
\text { numbers) }\end{array}$ & $\begin{array}{l}\text { Published } \\
\text { sequences } \\
\text { ( } \mathrm{N} \text { and GenBank } \\
\text { accession numbers) }\end{array}$ & $\begin{array}{l}\mathrm{N} \text { (pooled } \\
\text { data) }\end{array}$ \\
\hline \multirow{10}{*}{ A. spp. } & $\begin{array}{l}\text { Northwestern } \\
\text { Spain }\end{array}$ & A Coruña & $\begin{array}{l}43^{\circ}=22^{\prime} 08^{\prime \prime} \mathrm{N}, 8^{\circ} \text { - } \\
24^{\prime} 31^{\prime \prime} \mathrm{W}\end{array}$ & $\begin{array}{l}14 \text { (MW506591 - } \\
\text { MW506616; } \\
\text { MW506713; } \\
\text { MW506714) }\end{array}$ & & 14 & $\begin{array}{l}13 \text { (MW506390 - } \\
\text { MW506402) }\end{array}$ & & 13 \\
\hline & North Portugal & Gaia & $\begin{array}{l}41 ㅇ ㅡ ㅇ 6^{\prime} 01^{\prime \prime} \mathrm{N}, 8 \text { 으 } \\
39^{\prime} 39^{\prime \prime} \mathrm{W}\end{array}$ & $\begin{array}{l}53 \\
\text { (MW506617 - } \\
\text { MW506648; } \\
\text { MW506715 } \\
\text { - MW506788) }\end{array}$ & $\begin{array}{l}\text { 14 (KP065513; } \\
\text { KP065530 } \\
\text {-KP065533; } \\
\text { KP065552 - } \\
\text { KP065560) }\end{array}$ & 67 & $\begin{array}{l}53 \text { (MW506403- } \\
\text { MW506455) }\end{array}$ & $\begin{array}{l}14 \\
\text { (KP090861- } \\
\text { KP090863, } \\
\text { KP090866, } \\
\text { KP090909- } \\
\text { KP090917, } \\
\text { KP090929) }\end{array}$ & 67 \\
\hline & & Baleal & $\begin{array}{l}39 \circ 19^{\prime} 28^{\prime \prime} \mathrm{N}, 9 \text { 으 } \\
21^{\prime} 39^{\prime \prime} \mathrm{W}\end{array}$ & & $\begin{array}{l}5 \text { (KP065546 } \\
\text {-KP065550) }\end{array}$ & 5 & & $\begin{array}{l}\text { 5(KP090856- } \\
\text { KP090858, } \\
\text { KP090860, } \\
\text { KP090876) }\end{array}$ & 5 \\
\hline & Central Portugal & Cabo Raso & $\begin{array}{l}38 \circ-42^{\prime} 33^{\prime \prime} \mathrm{N}, 9 \circ \\
29^{\prime} 11^{\prime \prime} \mathrm{W}\end{array}$ & & $\begin{array}{l}19 \text { (KP065503- } \\
\text { KP065511; } \\
\text { KP065520 } \\
- \text { КР065529) }\end{array}$ & 19 & & $\begin{array}{l}17 \text { (KP090890 - } \\
\text { KP090894, } \\
\text { KP090896 - } \\
\text { KP090900, } \\
\text { KP090902 - } \\
\text { KP090908) }\end{array}$ & 17 \\
\hline & & Ericeira & $\begin{array}{l}38 ㅇ 8^{\prime} 09^{\prime \prime} \mathrm{N}, 9 \text { 으 } \\
25^{\prime} 15^{\prime \prime} \mathrm{W}\end{array}$ & & $\begin{array}{l}2 \text { (KP065502; } \\
\text { KP065551) }\end{array}$ & 2 & & 1(KP090889) & 1 \\
\hline & & Mindelo & $\begin{array}{l}38 ㅇ=49^{\prime} 45^{\prime \prime} \mathrm{N}, 9 \text { 으 } \\
28^{\prime} 07^{\prime \prime} \mathrm{W}\end{array}$ & & $\begin{array}{l}\text { 12 (KP065497 - } \\
\text { KP065501; } \\
\text { KP065514- } \\
\text { KP065519; } \\
\text { KP065512) }\end{array}$ & 12 & & $\begin{array}{l}\text { 11(KP090878- } \\
\text { KР090888) }\end{array}$ & 11 \\
\hline & & Praia da Luz & $\begin{array}{l}37 \circ 05^{\prime} 11^{\prime \prime} \mathrm{N}, 8^{\circ} \text { - } \\
43^{\prime} 31^{\prime \prime} \mathrm{W}\end{array}$ & $\begin{array}{l}18 \\
\text { (MW506663 - } \\
\text { MW506690; } \\
\text { MW506789 - } \\
\text { MW506796) }\end{array}$ & & 18 & $\begin{array}{l}\text { 18(MW506456 - } \\
\text { MW506473) }\end{array}$ & & 18 \\
\hline & South Portugal & Olhos de Água & $\begin{array}{l}37 \circ 05^{\prime} 26^{\prime \prime} \mathrm{N}, 8 \text { 으 } \\
10^{\prime} 53^{\prime \prime} \mathrm{W}\end{array}$ & $\begin{array}{l}7 \\
\text { (MW506649 - } \\
\text { MW506662) }\end{array}$ & & 7 & $\begin{array}{l}\text { 7(MW506474 - } \\
\text { MW506480) }\end{array}$ & & 7 \\
\hline & & Portimão & $\begin{array}{l}377^{\circ} 06^{\prime} 30^{\prime \prime} \mathrm{N}, 8^{\circ} \text { - } \\
31^{\prime} 31^{\prime \prime} \mathrm{W}\end{array}$ & & $\begin{array}{l}\text { KP12 (065534 } \\
- \text { KP065545) }\end{array}$ & 12 & & $\begin{array}{l}12 \text { (KP090867 - } \\
\text { KP090875, } \\
\text { KP090930 } \\
- \text { KP090932) }\end{array}$ & 12 \\
\hline & Southern Spain & Tarifa & $\begin{array}{l}36 \circ 00^{\prime} 28^{\prime \prime} \mathrm{N}, 5^{\circ} \text { - } \\
36^{\prime} 20^{\prime \prime} \mathrm{W}\end{array}$ & $\begin{array}{l}11 \\
\text { (MW506691 - } \\
\text { MW506712) }\end{array}$ & & 11 & & & \\
\hline \multirow{7}{*}{ A. fragacea } & $\begin{array}{l}\text { Northwestern } \\
\text { Spain }\end{array}$ & A Coruña & $\begin{array}{l}43 ㅇ ㅡ 2^{\prime} 08^{\prime \prime} \mathrm{N}, 8^{\circ} \text { - } \\
24^{\prime} 31^{\prime \prime} \mathrm{W}\end{array}$ & $\begin{array}{l}8 \\
\text { (MW506517- } \\
\text { MW506532) }\end{array}$ & & 8 & $\begin{array}{l}8 \\
\text { (MW506481 - } \\
\text { MW506488) }\end{array}$ & & 8 \\
\hline & North Portugal & Gaia & $\begin{array}{l}41^{\circ} \quad 06^{\prime} 01^{\prime \prime} \mathrm{N}, 8^{\circ}- \\
39^{\prime} 39^{\prime \prime} \mathrm{W}\end{array}$ & $\begin{array}{l}16 \\
\text { (MW506533 - } \\
\text { MW506564) }\end{array}$ & $\begin{array}{l}\text { 2(KP065584; } \\
\text { KР065585) }\end{array}$ & 18 & $\begin{array}{l}15 \\
\text { (MW506489 - } \\
\text { MW506503) }\end{array}$ & 1(KР090928) & 16 \\
\hline & & Baleal & $\begin{array}{l}39 ㅇ ㅡ 9^{\prime} 28^{\prime \prime} \mathrm{N}, 9 \text { 으 } \\
21^{\prime} 39^{\prime \prime} \mathrm{W}\end{array}$ & & $\begin{array}{l}2 \text { (KP065565; } \\
\text { KP065567) }\end{array}$ & 2 & & 1(KP090918) & 1 \\
\hline & & Cabo Raso & $\begin{array}{l}38 \circ-42^{\prime} 33^{\prime \prime} \mathrm{N}, 9 \circ \\
29^{\prime} 11^{\prime \prime} \mathrm{W}\end{array}$ & & $\begin{array}{l}8 \text { (KP065574 - } \\
\text { KP065581) }\end{array}$ & 8 & & $\begin{array}{l}\text { 5(КР090922 - } \\
\text { КР090926) }\end{array}$ & 5 \\
\hline & & $\begin{array}{l}\text { São João do } \\
\text { Estoril }\end{array}$ & $\begin{array}{l}38 \circ-41^{\prime} 17^{\prime \prime} \mathrm{N}, 9 \circ \\
21^{\prime} 19^{\prime \prime} \mathrm{W}\end{array}$ & & $\begin{array}{l}2 \text { (KP065582; } \\
\text { KP065583) }\end{array}$ & 2 & & 1(KP090927) & 1 \\
\hline & $\begin{array}{l}\text { Central } \\
\text { Portugal }\end{array}$ & $\begin{array}{l}\text { Mindelo - } \\
\text { Sintra }\end{array}$ & $\begin{array}{l}38 ㅇ 9^{\prime} 45^{\prime \prime} \mathrm{N}, 9 \text { 으 } \\
28^{\prime} 07^{\prime \prime} \mathrm{W}\end{array}$ & & $\begin{array}{l}6 \text { (KP065568 - } \\
\text { KР065573) }\end{array}$ & 6 & & $\begin{array}{l}\text { 3(KP090919- } \\
\text { KP090921) }\end{array}$ & 3 \\
\hline & South Portugal & Portimão & $\begin{array}{l}37 ㅇ ㅡ ㅇ 6^{\prime} 30^{\prime \prime} \mathrm{N}, 8 \text { 으 } \\
31^{\prime} 31^{\prime \prime} \mathrm{W}\end{array}$ & $\begin{array}{l}13 \\
\text { (MW506565 - } \\
\text { MW506590) }\end{array}$ & $\begin{array}{l}2 \text { (KP065586; } \\
\text { KP065587) }\end{array}$ & 15 & $\begin{array}{l}13 \text { (MW506504 - } \\
\text { MW506516) }\end{array}$ & $\begin{array}{l}\text { 2(KP090864, } \\
\text { КР090865) }\end{array}$ & 15 \\
\hline
\end{tabular}

presenting heterozygous indels were manually phased following the procedure described in Sousa-Santos et al. (2005). Arlequin software package version 3.01 (Excoffier and Schneider, 2005) was used to reconstruct the individual alleles (haplotypes) present, using the ELB algorithm (28S). Relationships among haplotypes were analyzed with a parsimony network estimated by the software TCS version 1.18 network (using default parameters, 95\% confidence) (Clement et al., 2000).

In order to validate morphologically the taxonomic status of each of the genetic groups identified, 10 individuals of Actinia spp. were collected in the rocky intertidal area of Parede (Central Portugal: $\left.38^{\circ} 41^{\prime} 17^{\prime \prime} \mathrm{N}, 9^{\circ} 21^{\prime} 19^{\prime \prime} \mathrm{W}\right)$. A small tissue clip of each individual was collected and preserved in $96 \%$ ethanol. The individuals were anesthetized with menthol crystals and preserved in $8 \%$ formalin. DNA was extracted from tissue clips, using the protocol described above, which allowed for the identification of the respective molecular haplogroup. Two individuals of each haplogroup found in this study and in Pereira et al. (2014) were selected and their general morphology was studied by means of a stereo dissecting microscope. Nematocysts were examined and studied with a light microscope equipped with a Nomarski differential interference contrast optic system. The classification and terminology of nematocysts followed that of Schmidt (1972), as adapted by den Hartog (1980) and den Hartog et al. (1993). After being fixed in the formaldehyde solution, the individuals were stored in $70 \%$ alcohol in the collections of the Museo del Mar de Ceuta (MMC-270 to MMC-275).

\section{Results and discussion}

Sequences from the fragment of the $28 \mathrm{~S}$ nuclear gene obtained from the 140 individuals (GenBank accession numbers from MW506517 to MW506796), revealed 15 different haplotypes, 12 of which were previously found by Pereira et al. (2014). When combining present and previously published sequences, 


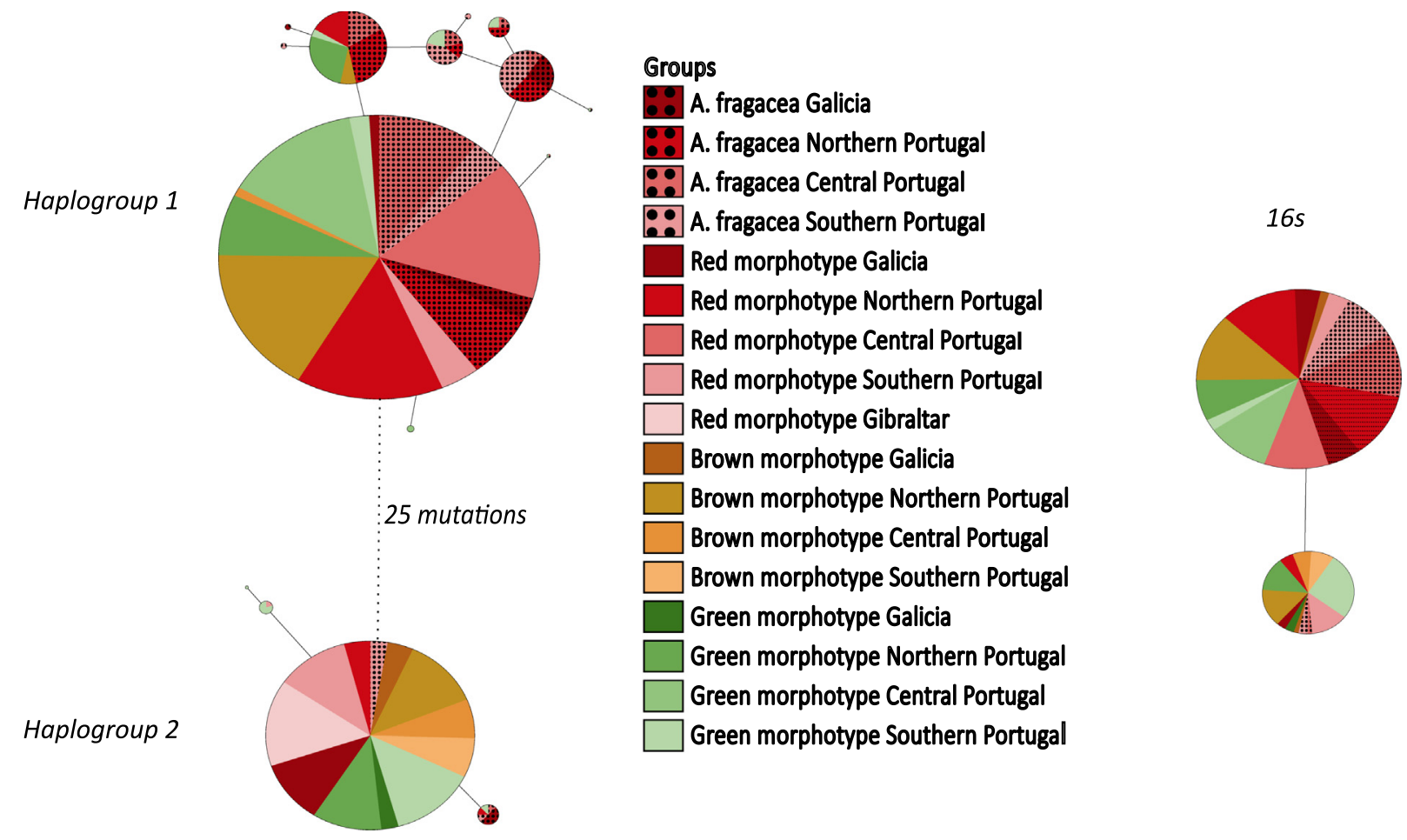

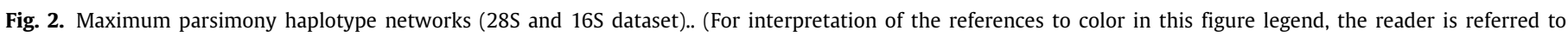
the web version of this article.)

the two haplogroups described by Pereira et al. (2014) were recovered in a parsimony network (Fig. 2). The most common haplogroup includes samples from plain color morphotypes (Actinia spp.) and from A. fragacea (Haplogroup 1). This group includes genetic sequences separated by 4 mutational steps and several shared sequences between morphotypes. Haplogroup 2 includes mostly plain color morphotypes, and a small proportion of $A$. fragacea. Both haplogroups include brown, green and red Actinia. In fact, red plain morphotype displays group 1 haplotypes in northwest Spain $(n=1)$, north $(n=18)$, central $(n=16)$ and south Portugal $(n=4)$, and group 2 haplotypes in northwest Spain $(n=8)$, north Portugal $(n=3)$, south Portugal $(n=9)$ and south Spain $(n=11)$. Plain brown morphotype display group 1 haplotypes in north $(\mathrm{n}=18)$ and central Portugal $(\mathrm{n}=1)$ and group 2 haplotypes in northwest Spain $(\mathrm{n}=3)$, north ( $\mathrm{n}$ $=9)$, central $(n=5)$ and south Portugal $(n=5)$. Finally, plain green morphotype display group 1 haplotypes in north $(\mathrm{n}=$ 11), central $(n=16)$ and south Portugal $(n=2)$ and group 2 haplotypes in northwest Spain $(\mathrm{n}=2)$ and north $(\mathrm{n}=8)$ and south Portugal $(n=17)$. Considering these results, the same cryptic speciation found in Pereira et al. (2014) is found, and both groups display color polymorphism, which cannot be used as a species discriminant character.

The fragment of 434bp of the mitochondrial 16S gene (GenBank accession numbers MW506390-MW506516), pooled with the previously available data, recovered only two 16S haplotypes in 200 individuals, separated by one mutation (Fig. 2). One of these haplotypes includes almost all the individuals belonging to $28 \mathrm{~S}$ haplogroup 2 (except for one specimen of $A$. fragacea collected in Central Portugal). The other haplotype includes mostly specimens of $28 \mathrm{~S}$ haplogroup 1 (plain color Actinia and $A$. fragacea), but $6 \%$ belongs to $28 \mathrm{~S}$ haplogroup 2 .

Morphological analyses on the homotrichs capsules (type of nematocyst located into the Acrorhagi with the tube arranged spirally all along the capsule) from individuals belonging to the two haplogroups (Fig. S1) show that haplogroup 1 is composed of individuals compatible with $A$. equina and $A$. fragacea and the haplogroup 2 with $A$. schmidti, all expected to be found in Portuguese coast from the results of previous morphological studies (den Hartog and Ocaña, 2003; Ocaña et al., 2005). Specimens of Actinia belonging to haplogroup 1 based on $28 \mathrm{~S}$ gene sequences (voucher specimen ACEQCPN49 and ACEQCPN55) have slender homotrichs never reaching $4 \mu \mathrm{m}$ in diameter, as expected for this species. In contrast, specimens belonging to haplogroup 2 considering 28S gene sequences (voucher specimens ACEQCPN49 and ACEQCPN53) have coarse homotrichs thicker and reach at least $4 \mu \mathrm{m}$ (see Ocaña et al., 2005). In these haplogroup 2 samples, pmastigophores B1 were present in the filaments. Although nematocyst measurements are considered to lack taxonomic utility in many groups of Cnidaria, these characters have been found useful in discriminating species in this particular genus by previous studies (e.g. Ocaña et al., 2005).

This paper provides evidence supporting the presence of $A$. fragacea, A. equina and $A$. schmidti in the Iberian Peninsula. The presence of these species in Iberia was previously been reported by den Hartog and Ates (2011) from Ria de Arosa in Galicia in Northwest Spain, although the authors stated that "Actinia equina is a species complex". In the same paper, following Schmidt (1972), the authors recognized the existence of two different subspecies belonging to the Actinia genus: Actinia equina mediterranea (now classified as $A$. schmidti, after the work of Monteiro et al., 1997) and Actinia equina equina. However, they did not identify which of them occurred in Galicia. With our results, the occurrence of three Actinia species (A. fragacea, A. equina and A. schmidtii) in Galicia was confirmed, as well as in northern, central and south Portugal, although at different relative abundances.

The relation between the $28 \mathrm{~S}$ haplogroups described in the present study and the three taxonomic units was corroborated by the morphological analysis. The discrimination between haplogroups confirmed that individuals from haplogroup 2 present homotrichs and p-mastigophore B1 in the filaments, a morphological feature described for A. schmidti (Ocaña et al., 2005). 
On the other hand, individuals belonging to $28 \mathrm{~S}$ haplogroup 1 have acrorhagial homotrichs with the tube partially spiral and absence of p-mastigophore B1 in the filaments, characteristics of a morphological group defined by Ocaña et al. in 2005 which included A. fragacea and A. equina. Within $28 \mathrm{~S}$ haplogroup 1 , further discrimination between these two species can be made based on the distinctive color patterns. The absence of genetic differentiation between $A$. equina and $A$. fragacea using this genetic marker, although not expected, is a common phenomenon in sea anemones. In fact, using the dataset of Daly et al. (2017) of the same molecular marker, we found that among the 19 groups of species of the same genera, three of them have an uncorrected p-distance lower than the one found between $A$. equina and $A$. fragacea.

In this paper, it is shown that the $28 \mathrm{~S}$ gene is clearly more efficient than the $16 \mathrm{~S}$ gene for species identification purposes. In fact, the $16 \mathrm{~S}$ gene shows no interspecific diversity and no variability within one of the three species (A. equina) and very limited diversity in the remaining two (A. fragacea and $A$. schmidti).

Nevertheless, these two species are genetically indistinguishable in our parsimony network based on $28 \mathrm{~s}$ gene, which is consistent with the view that $A$. equina and $A$. fragacea are very closely related species, having diverged recently (Solé-Cava et al., 1994). The fact that $5 \%$ of $A$. fragacea samples (two individuals) are placed in the same haplogroup as $A$. schmidti in the parsimony network (haplogroup 2) can be an artifact due to misidentification. However, it can also result from a higher level of color polymorphism in this species than previously reported, which should be investigated and clarified in the future.

The fact that $A$. equina and $A$. schmidti are macroscopically impossible to distinguish, both presenting different color morphotypes in the sampled areas, argues for the importance of molecular data for species identification in conjunction with morphological analyses. DNA barcoding, widely used in other taxonomic groups, has shown to have a restricted application on some groups of Anthozoa - the selected marker for barcoding in animals, a mitochondrial DNA sequence (cytochrome oxidase I), has a very slow rate of evolution in some groups of Cnidaria (e.g. in corals; Shearer et al., 2002; Hellberg, 2006), while effective in others (Stampar et al., 2014; Ortman et al., 2010). Other markers have been tested, but the efforts to find a universal Cnidaria marker have not yet been successful (e.g. Worthington Wilmer and Mitchell, 2008; Dohna and Kochzius, 2015).

\section{CRediT authorship contribution statement}

Ana M. Pereira: Conceptualization, Methodology, Formal analysis, Investigation, Writing. Emília Cadeireiro: Investigation. Oscar Ocaña: Methodology, Investigation, Writing - review \& editing. Jasna Vukić: Investigation, Writing - review \& editing. Radek Šanda: Investigation, Writing - review \& editing. Luca Mirimin: Investigation, Writing - review \& editing. Joana I. Robalo: Methodology, Investigation, Resources, Writing - review \& editing.

\section{Declaration of competing interest}

The authors declare that they have no known competing financial interests or personal relationships that could have appeared to influence the work reported in this paper.

\section{Acknowledgments}

This study had the support of Fundação para a Ciência e Tecnologia (FCT), through the strategic project MARE/UIDB/MAR/ 04292/2020 granted to MARE, the Ministry of Culture of the Czech Republic (DKRVO 2015/15, National Museum, 00023272) and by the institutional resources of the Ministry of Education, Youth, and Sports of the Czech Republic. We want to thank João Paulo Fonseca, Sara Francisco, Rocío Peréz-Portela, Joana Sanches, Cristiana Brito and Bernardo Machado for their help in specimens' collection, and Sara Francisco for reviewing the manuscript.

\section{Appendix A. Supplementary data}

Supplementary material related to this article can be found online at https://doi.org/10.1016/j.rsma.2021.101648.

\section{References}

Carter, M.A., Thorpe, J.P., 1981. Reproductive, genetic and ecological evidence that Actinia equina var.mesembryanthemum and var. fragacea are not conspecific. J. Mar. Biol. Ass. U. K. 61, 79-83.

Cha, H.-R., Buddmeier, R.W., Fautin, D.G., Sandhei, P., 2004. Distribution of sea anemones (Cnidaria, Actiniaria) in Korea analysed by environmental clustering. Hydrobiologia 530/531, 497-502. http://dx.doi.org/10.1007/s10750-0042667-3.

Clement, M., Posada, D., Crandall, K.A., 2000. TCS: a computer program to estimate gene genealogies. Mol. Ecol. 9, 1657-1659. http://dx.doi.org/10. 1046/j.1365-294x.2000.01020.

Daly, M., Crowley, L.M., Larson, P., Rodriguez, E., Saucier, E.H., Fautin, D.G., 2017. Anthopleura and the phylogeny of Actinoidea (Cnidaria: Anthozoa: Actiniaria). Org. Divers. Evol. 17, 545-564. http://dx.doi.org/10.1007/s13127017-0326-6.

Daly, M., Fautin, D., 2020. World list of actiniaria. actinia linnaeus, 1767. World register of marine species. http://www.marinespecies.org/aphia.php? $\mathrm{p}=$ taxdetails\&id=100694 (accessed 19 November 2020).

Daly, M., Gusmão, M.C., Reft, A.J., Rodriguez, E., 2010. Phylogenetic signal in mitochondrial and nuclear markers in sea anemones (Cnidaria, Actiniaria). Integr. Comp. Biol. 50 (3), 371-388. http://dx.doi.org/10.1093/icb/icq081.

Dohna, T.A., Kochzius, M., 2015. Obstacles to molecular species identification in sea anemones (Hexacorallia: Actiniaria) with COI, a COI intron, and ITS II. Mar. Biodivers. 46, 291-297. http://dx.doi.org/10.1007/s12526-015-0329-5.

Excoffier, L.G.L., Schneider, S., 2005. Arlequin ver. 3.0: an integrated software package for population genetics data analysis. Evol. Bioinform. Online 1, 47-50. http://dx.doi.org/10.1177/117693430500100003.

Fautin, D.G., 2016. Catalog to families, genera, and species of orders Actiniaria and Corallimorpharia (Cnidaria: Anthozoa). Zootaxa 4145 (1), 1-449. http: //dx.doi.org/10.11646/zootaxa.4145.1.1.

Geller, J.B., Walton, E.D., 2001. Breaking up and getting together: evolution of symbiosis and cloning by fission in sea anemones (genus anthopleura). Evolution 55, 1781-1794. http://dx.doi.org/10.1111/j.0014-3820. 2001.tb00827.

den Hartog, J.C., 1980. Caribbean shallow water corallimorpharia. Zool. Verh. 176, $1-83$.

den Hartog, J.C., Ates, R.M.L., 2011. Actiniaria from Ria de Arosa, Galicia, northwestern Spain. Zool. Meded. 85, 11-53.

den Hartog, J.C., Ocaña, O., 2003. A new endemic actinia species (Actiniaria: Actiniidae) from the central Macaronesian Archipelagos. Zool. Meded. 77, 229-244.

den Hartog, J.C., Ocaña, O., Ates, R.M.L., 1993. Corallimorpharia collected during the CANCAP expedition (1976-1986) in the south-eastern part of the North Atlantic. Zool. Verh. 282, 1-76.

Hellberg, M.E., 2006. No variation and slow synonymous substitution rates in coral mtDNA despite high nuclear variation. BMC Evol. Biol. 6, 24. http: //dx.doi.org/10.1186/1471-2148-6-24.

Manuel, R.L., 1981. Bristish Anthozoa. Academic Press, London, p. 241.

Monteiro, F.A., Solé-Cava, A.M., Thorpe, J.P., 1997. Extensive genetic divergence between populations of the common intertidal sea anemone Actinia equina from Britain, the Mediterranean and the Cape Verde Islands. Mar. Biol. 129, 425-433. http://dx.doi.org/10.1007/s002270050183.

Ocaña, O., Brito, A., González, G., 2005. The genus Actinia in the macaronesian archipelagos: a general perspective of the genus focussed on the Northoriental Atlantic and the Mediterranean species (Actiniaria: Actiniidae). Vieraea 33, 477-494.

Ortman, B.D., Bucklin, A., Pagès, F., Youngbluth, M., 2010. DNA barcoding the Medudozoa using mtCOI. Deep Sea Res. 57, 2148-2156. http://dx.doi.org/10. 1016/j.dsr2.2010.09.017. 
Pereira, A.M., Brito, C., Sanches, J., Sousa-Santos, C., Robalo, J.I., 2014. Absence of consistent genetic differentiation among several morphs of Actinia (Actiniaria: Actiniidae) occurring in the Portuguese coast. Zootaxa 3893, 595-600. http://dx.doi.org/10.11646/zootaxa.3893.4.9.

Schama, R., Mitchell, M., Solé-Cava, A.M., 2012. Actinia ebhayiensis sp. Nov. a new species of sea anemone (Anthozoa: Actiniaria: Actiniidae) from South Africa. J. Mar. Biol. Ass. U.K. 92, 885-894. http://dx.doi.org/10.1017/ S0025315411001305.

Schmidt, H., 1972. Prodromus zu einer Monographie der mediterranen Aktinien. Zoologica Stuttgart 121, 1-146.

Shearer, T.L., Van Oppen, M.J.H., Romanom, S.L., Worheide, G., 2002. Slow mitochondrial DNA sequence evolution in the Anthozoa (Cnidaria). Mol. Ecol. 11, 2475-2487. http://dx.doi.org/10.1046/j.1365-294X.2002.01652.x.

Solé-Cava, A.M., Russo, C.A.M., Araújo, M.E., Thorpe, J.P., 1994. Cladistic and phenetic analysis of allozyme data for nine species of sea anemones of the family Actiniidae (Cnidaria: Anthozoa). Biol. J. Lin. Soc. 52, 224-239. http://dx.doi.org/10.1111/j.1095-8312.1994.tb00988.x.

Solé-Cava, A.M., Thorpe, J.P., 1987. Further genetic evidence for the reproductive isolation of the green anemone Actinia prasina Gosse from common intertidal beadlet anemone Actinia equina (L.). Mar. Ecol. Prog. Ser. 38, 225-229.
Sonnenberg, R., Nolte, A.W., Tautz, D., 2007. An evaluation of LSU rDNA D1D2 sequences for their use in species identification. Front. Zool. 4, 1-6. http://dx.doi.org/10.1186/1742-9994-4-6.

Sousa-Santos, C., Robalo, J.I., Collares-Pereira, M.J., Almada, V.C., 2005. Heterozygous indels as useful tools in the reconstruction of DNA sequences and in the assessment of ploidy level and genomic constitution of hybrid organism. DNA Seq. 16, 462-467. http://dx.doi.org/10.1080/10425170500356065.

Stampar, S.N., Maronna, M.M., Kitahara, M.V., Reimer, J.D., Morandini, A.C., 2014. Fast-evolving mitochondrial DNA in Ceriantharia: a reflection of Hexacorallia paraphyly? Plos One 9, 1-10. http://dx.doi.org/10.1371/journal.pone. 0086612.

Stephenson, T.A., 1935. The British Sea Anemones. Ray Society, London, p. 426.

Thompson, J.D., Gibson, T.J., Plewniak, F., Jeanmougin, F., Higgins, D.G., 1997. The clustalx windows interface: flexible strategies for multiple sequence alignment aided by quality analysis tools. Nucleic Acids Res. 24, 4876-4882. http://dx.doi.org/10.1093/nar/25.24.4876.

Worthington Wilmer, J., Mitchell, M.L., 2008. A preliminary investigation of the utility of ribosomal genes for species identification of Sea Anemones (Cnidaria: Actiniaria). Mem Queen. Mus. 54, 65-73. 